\title{
Cheating Intention of Students Based on Theory of Planned Behavior
}

\author{
Patriani Wahyu Dewanti ${ }^{1^{*}}$, Ida Ayu Purnama ${ }^{2}$, Merinda NN Siregar ${ }^{3}$, \\ Sukirno $^{4}$
}

\section{AFFILIATION:}

1,3,4 Faculty of Economics, Universitas Negeri Yogyakarta, Indonesia

${ }^{2}$ Faculty of Economics and Business, Universitas Pembangunan Nasional Veteran Yogyakarta, Indonesia

\section{*CORRESPONDENCE:}

patriani_wd@uny.ac.id

THIS ARTICLE IS AVAILABLE IN:

https://ojs.unud.ac.id/index.php/jiab

DOI:

10.24843/JIAB.2020.v15.i02.p09

\section{CITATION:}

Dewanti, P. W., Purnama, I. A., Siregar, M. NN., \& Sukirno. (2020). Cheating Intention of Students Based on Theory of Planned Behavior. Jurnal Ilmiah Akuntansi dan Bisnis, 15(2), 268-279.

\section{ARTICLE HISTORY}

Received:

17 December 2019

Revised:

02 June 2020

\section{Accepted:}

22 June 2020

\begin{abstract}
The aim of this research is to examine empirically the form of Theory of Planned Behavior in predicting the intention of cheating in accounting students. The samples taken in this research were 426 accounting students. The research employed a mixed-method, with a regression analysis for the quantitative and an analytic induction for the qualitative method. The results of this research found that of all the variables tested, subjective norms were the variables that had the greatest influence on the intention to cheat accounting students, while the moral obligation variable had the second largest influence and perceived behavioral control as the third predictor on the intention to cheat accounting students. The implication of the research is that the main influence of the academic fraud is subjective norms.
\end{abstract}

Keywords: Theory of planned behavior, subjective norms, academic integrity.

\section{Introduction}

Academic integrity behavior is one of the main problems in universities (Davis, Drinan \& Gallant, 2009; Schwartz, Tatum, \& Hageman, 2013). Students do cheat behavior towards violations of academic integrity such as cheating assignments because students see their classmates doing the same thing and this behavior considered to be something normal among students (Schwartz et al., 2013). The normal behavior justify the students that cheating is not a violation, thus this razionalization plays a crucial act in students improprieties (Macgregor \& Stuebs, 2012). Bujaki, Lento, \& Sayed (2019) used triangle fraud to research the academic fraud in accounting education. First, the razionalitation driven by student such as students motivation to cheat and faculty driven attitude in control students to do academic fraud. Second, the pressure corners also driven by faculty and student such as the exam is too difficult or students have a pressure to achieve good grades. Third, the opportunity element is within a professor's control such as using various exams will prevent the students to copy each other.

Academic dishonesty is usually caused by several factors, namely subjective norms, behavior, moral obligations and past behavior (Ajzen, 2002). Many students who see cheating is not an academic offence; they 


\section{Dewanti, Purnama, Siregar \& Sukirno \\ Cheating Intention of Students Based on Theory of Planned Behaviour}

see it as a form of an effort to achieve good grades. Students do not realize that such behavior is one of the academic violations (Cronan, Mullins, \& Douglas, 2018a). Some of the factors that cause cheating are as follows: (1) opportunities that occur in situations where students can access online resources, for example, 20 percent of students' final assignments quoted from the web, (2) the desire to succeed and win, makes students do everything they can to achieve one of them by cheating, they thought that people would respect them if they have a high GPA without recognition to the non-academic abilities, (3) the absence or lack of penalties or penalties from lecturers for cheating. Some studies suggest that another reason for students cheating is their low perceived morality (Simkin \& McLeod, 2010). What is suprising, however, students strive for perception of the higher academic achievement, measured by grades in order to entice desirable employers that offer higher levels of income (Winrow, 2016)

Cronan et al. (2018) researched academic integrity violations that focused on plagiarism and cheating on students. The research examined 1,300 students for two years. This research examines the model of the intentions of plagiarism and cheating using the factors of the theory of planned behavior (TPB). The results showed that all elements of TPB, namely attitudes, perceived behavioral control, subjective norms, past behavior and moral obligations, significantly influence the intention to cheat among students. Another research by Chudzicka-Czupała et al. (2016), examined the application of TPB in academic cheating by comparing seven countries, namely Poland, Ukraine, Romania, Turkey, Switzerland, the United States and New Zealand. The research conducted on 2,021 students for two years. This research states that attitudes, perceived behavioral control, and moral obligation give a strong influence on the intention to cheat students.

This research focuses on academic integrity behavior cheating on college assignments because college assignments are activities that are given to lecturers routinely at each meeting. Hence, students consider college assignments to be routine, and if copying the work of others is considered to be something frequent and not irregular academic integrity. This habit can carry over to their future work as an accountant. Ballantine, McCourt Larres, \& Mulgrew (2014) stated that ethical ideology and idealism in cheating have a positive significant for improving the reputation of irish accountancy proffesion. Moral dimensions really important in the proffesional accounting community, they will not tolerate ethical misconduct and will impose several punishments for members who cheat (Ismail, S., \& Yussof, 2016).

Main focus of this research is to empirically examine the theoretical form of the Theory of Planned Behavior (TPB) as a research model to predict the intentions of cheating behavior in accounting research program students. Empirical testing is to see how the impact of the independent variable attitude, subjective norms, perceived behavior, moral obligation and past behavior on the intention to cheat assignments to accounting students and which independent variable has the most dominant on the intention to copy.

TPB states that an individual decides to participate in behavior based on their beliefs about the ethics and their expectation that the act provides positive results. These beliefs and expectations constitute three constructs on the core theory of TPB, namely: (1) attitudes toward behavior, which originate from past individual experiences and evaluations by individuals, whether the act will cause positive and negative effects or something beneficial or unprofitable; (2) subjective norms derived from the social 


\section{Dewanti, Purnama, Siregar \& Sukirno \\ Cheating Intention of Students Based on Theory of Planned Behaviour}

environment of individuals who shape the behavior of individuals who show indications of whether others judge it as appropriate or inappropriate behavior and also the social pressure to participate or not participate in action; (3) the level of perceived behavioral control which, as previously discussed, refers to the perception of the ease or difficulty of conducting behavior, and is assumed to reflect past experiences as anticipated obstacles and obstacles (perceived behavioral control). These three constructs affect the intention or purpose of someone in behaving and the level of control over circumstances that can prevent individuals from engaging in such behavior (Madden, Ellen, \& Ajzen, 1992). Intention-Intention to behave ethically/unethically (intention) is the intention of an individual to do or not to do specific behavior (in this case, to commit an academic violation of integrity)

Beck \& Ajzen (1991) add one other factor related to the cause of individual behavior, namely moral obligation. This factor explains that there is a moral obligation to engage in a particular action related to the individual's personal feelings, which is reflected by feelings of guilt, reluctance to conduct practice or feel that the behavior is not following the principles of the value of the individual concerned (Ajzen, 2002).

Additionally, another factor that can affect the intentions of a person's behavior is past behavior. Some research states that there is a relationship between consistent over dishonest behavior over time (Beck \& Ajzen, 1991). Act in the past cannot be changed, and this is important because unethical behavior can carry over from high school to the workplace (Cronan et al., 2018a). Immoral behavior that carries over to the workplace can cause individuals to take unethical actions. Youngsters did cheating behavior when in high school, they knew that cheating was an unethical behavior, but their friends di the same behavior to get good grades which then carried up to the college and to the workplace which can result in acts of fraud, or conduct unethical earnings management techniques that can lead to accounting scandals as happened in the case of Enron, Worldcom, Tyco and others. The research undertaken by Hermawan showed that there is a significant relationship between behavior, intentions and perceptions, and students' perceptions of accounting ethics are fundamental because it will affect their attitudes and practice in the future (Tavani, 2013)

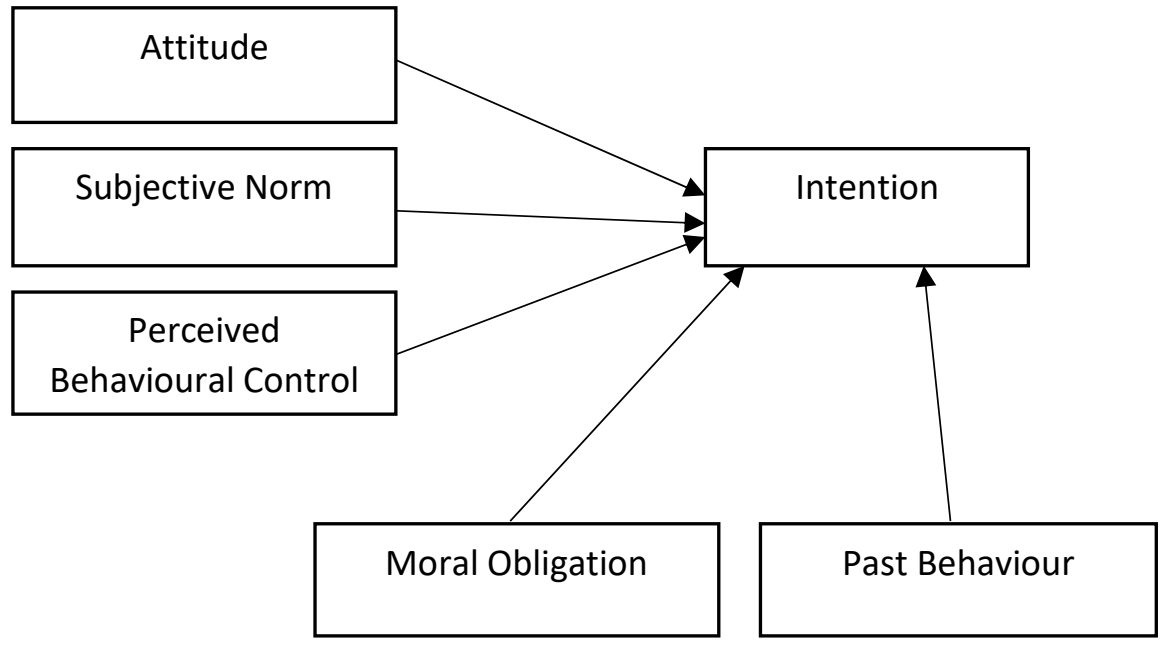

Figure 1. Extended TPB AI Homework and Plagiarism Violation Intention

Source: Cronan, Mullins, \& Douglas, 2018b 
Attitude is one of the main components in the theory of planned behavior and is also a strong predictor of intention. Attitude also measures the efforts of students who claim that cheating is justified and determining whether to graduate or not from the university, or fraud is justified if a close friend asks for help (Jordan, 2001). Furthermore, the independent determinant of intention is a social factor called the subjective norm. This norm refers to the attitude or behavior of an individual to do or not do an action (Ajzen, 2002). Furthermore, this research aims to investigate the influential factors of Theory of Planned Behavior (TPB) to predict the intention to cheat students' behavior in accounting students. Prior studies have eagerly showed their attention to explore the determinant of the student's intention to cheat framed by theory of plan behavior. Cronan (2018) for instance, found that attitude, subjective norms, perceived behavior control, moral obligation, and past behavior significantly affect individual's intention to violate academic integrity in assignments and plagiarism. Further, Chudzicka-Czupała, et.al (2016), confirmed that attitude, perceived behavior control, moral obligation can predict student's intention to engage in academic dishonesty in the form of cheating. In addition, Jalilian, Moazami, Mirzaei-Alavijeh, Moazami, \& Jalili (2016) stated that perceived behavior, attitude, sensation seeking adn subjective norms have shown a significant correlation with intention to cheat. Based on the empirical findings, this study proposes a hypothesis as follows.

$\mathrm{H}_{\mathrm{a}}$ : Attitude, subjective norms, perceived behavioral control, moral obligation and past

behavior significantly influences cheating intention of accounting students.

\section{Research Method}

This research explored the attitudes phenomenon based on gender, length of research and type of universities. This research employed a sequential mixed-method which combined quantitative and qualitative data (Sekaran \& Bougie, 2016). The types of this research was an explanatory or analytical research, that describe the characteristics of a phenomenon to analyzing and explaining why or how it is happening (Elijido-Ten, 2007). It involved a two-phase data collection project in which the researcher collected quantitative data in the first phase, analyzed the results, and then used the results to use the qualitative method. The qualitative data were collected by interviewing ten respondents that give direct answers. This interview was used to explain the contradictory or unusual responses. At the end, the qualitative and quantitative data were mixed to reveal more detail about the research result.

\section{Phase 1}

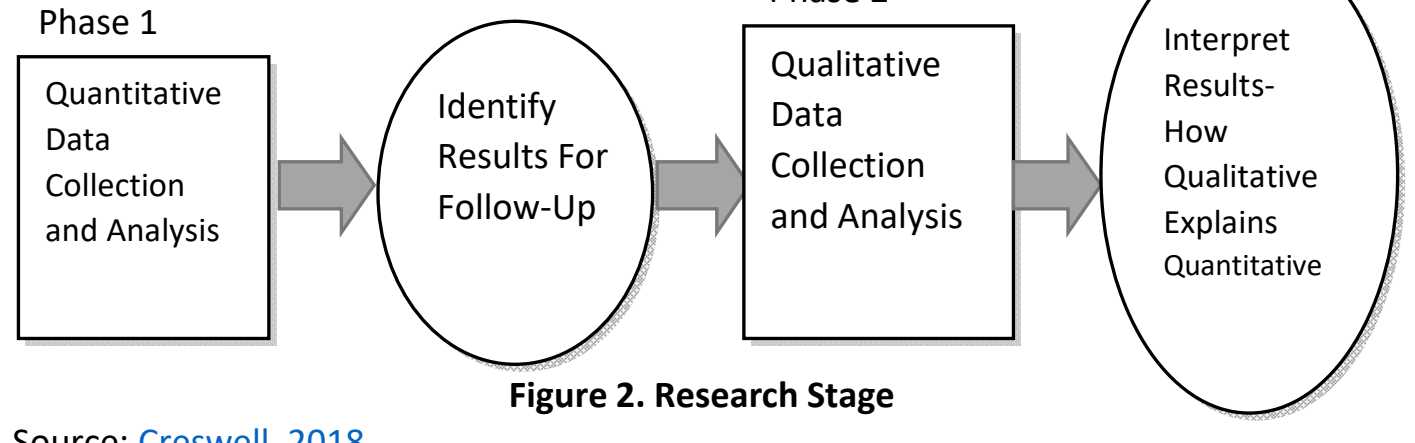

Source: Creswell, 2018 


\section{Dewanti, Purnama, Siregar \& Sukirno \\ Cheating Intention of Students Based on Theory of Planned Behaviour}

The data collection proceeded in two distinct phases with rigorous quantitative sampling in the first phase and with purposeful sampling in the second, qualitative phase. The data were collected in a longitudinal that managed one by one in one time (Creswell, 2018).

The quantitative and qualitative databases are analyzed separately in this approach. Then the researcher combines the two databases by the form of integration. The last step was interpretation This interpretation follows the structure of first reporting the quantitative, first-phase results and then the qualitative, second phase results.

The population of this research was accounting students from four universities (two state and two private). The sampling using purposive sampling, which specific criteria were students who passed the ethics profession and business course. Also, instruments of this research were taken from research conducted by Cronan (Cronan et al., 2018a).

The quantitative results typically inform the types of participants to be purposefully selected for the qualitative phase and the types of questions that will be asked of the participants (Creswell, 2018). The quantitative data were analyzed using simple regression to find out the quantitative effect for each independent variables to dependent variables ( $R$ square) (Pallant, 2010).

Analytic induction technique was used to analyze the qualitative data. It was conducted by a progressive redefinition of a concept by collecting data, developing analysis, and organizing the findings to construct and testing causal links between events and actions (Kabbanji, 2015). The methodology of analytical induction is inspecting initial cases to identify common factors and the seek explanation for existing linkages, and reworking the explanations based on the findings from new cases. Further, the success of this techniques depends on testing cases with new varieties of data to validate or revise established linkages, until negative cases cease to exist.

\section{Result and Discussion}

This research investigated the variables that have the highest significant influence on the academic integrity of cheating intentions in accounting students. In this research, the distribution of the questionnaire was carried out by direct and online distribution methods at four tertiary institutions in Yogyakarta. Furthermore, the university divided into four universities which are two private universities and two state universities.

Worked with 431 questionnaires, finally there were 426 respondent data can be further analyzed. The data consisted of 224 respondents from state universities and 207 respondents from private universities. In gender, there were 119 male students and 308 female students who participated in this research. Table 1. illustrates the combination of graphs between gender and the length of the research experienced by respondents.

Table 1. Gender and Length of Study Students

\begin{tabular}{lccc}
\hline \multirow{2}{*}{ Gender } & \multicolumn{3}{c}{ Semester } \\
\cline { 2 - 4 } & III & V & VII \\
\hline Female & 112 & 188 & 8 \\
Male & 40 & 63 & 15 \\
\hline
\end{tabular}

Source: Processed Data, 2019 
Dewanti, Purnama, Siregar \& Sukirno

Cheating Intention of Students Based on Theory of Planned Behaviour

Table 2. Validity Test

\begin{tabular}{ccccc}
\hline Variable & Item & r count & r table & Information \\
\hline INT & Question 1 & 0,952 & 0,098 & Valid \\
INT & Question 2 & 0,955 & 0,098 & Valid \\
INT & Question 3 & 0,955 & 0,098 & Valid \\
ATT & Question 1 & 0,329 & 0,098 & Valid \\
ATT & Question 2 & 0,649 & 0,098 & Valid \\
ATT & Question 3 & 0,571 & 0,098 & Valid \\
ATT & Question 4 & 0,333 & 0,098 & Valid \\
SN & Question 1 & 0,854 & 0,098 & Valid \\
SN & Question 2 & 0,826 & 0,098 & Valid \\
SN & Question 3 & 0,484 & 0,098 & Valid \\
PBC & Question 1 & 0,816 & 0,098 & Valid \\
PBC & Question 2 & 0,827 & 0,098 & Valid \\
PBC & Question 3 & 0,844 & 0,098 & Valid \\
PBC & Question 4 & 0,797 & 0,098 & Valid \\
PBC & Question 5 & 0,406 & 0,098 & Valid \\
MO & Question 1 & 0,172 & 0,098 & Valid \\
MO & Question 2 & 0,784 & 0,098 & Valid \\
MO & Question 3 & 0,773 & 0,098 & Valid \\
PB & Question 1 & 0,893 & 0,098 & Valid \\
PB & Question 2 & 0,849 & 0,098 & Valid
\end{tabular}

Source: Processed Data, 2019

The researcher eliminated some data that considered to cause interference in the subsequent analysis. The omitted data consisted of five data from semester II students (1 data), semester IV (1 data), semester VI (1 data), and semester VIII ( 2 data). Assumed that the data is an outlier when compared to other data. In the end, this research was used the remaining 426 data for more in-depth analysis. The data consisted of two state universities (222 respondents) and two private universities (204 respondents).

As can be seen from the data that the respondents in this research was dominated by female students who research in the fifth semester, the amount was 188 respondents. The number is nearly three times of male respondents in semester five which were 63 respondents. Similar finding was also found in respondents for the third semester, where female respondents (as many as 112 respondents) had nearly three times the number of student respondents (as many as 40 respondents). Table 2. showed the validity test of each variable.

Instrument testing (validity and reliability) was carried out by researchers to ensure that the instrument was feasible to be used in measuring research variables. Pearson correlation product-moment method was used to test the validity and Cronbach's alpha method was used to test the instrument's reliability. Some instrument items that were deemed not to meet the testing criteria were written off by the researcher to obtain the expected instrument eligibility. At the end, the validity test result indicate that instruments are valid and reliable.

Meanwhile, the realibility test was conducted for the instruments in this research. The reliability test is the degree to which research method produces stable and consistent results (Pallant, 2010). 
Dewanti, Purnama, Siregar \& Sukirno

Cheating Intention of Students Based on Theory of Planned Behaviour

Table 3. Reliability Test

\begin{tabular}{|c|c|c|c|}
\hline Variables & Cronbach's Alpha & Criteria & Information \\
\hline INT & 0,950 & 0,60 & Reliable \\
\hline ATT & 0,746 & 0,60 & Reliable \\
\hline SN & 0,829 & 0,60 & Reliable \\
\hline PBC & 0,879 & 0,60 & Reliable \\
\hline MO & 0,770 & 0,60 & Reliable \\
\hline PB & 0,679 & 0,60 & Reliable \\
\hline
\end{tabular}

Source: Processed Data, 2019

It can be seen in the Table 3., the reliability test conducted for each variable. All of the variables showed that the Croncabh's Alpha was higher than the criteria which was 0,60 , it can be concluded that all of the instruments were reliable. In the forward, the hypothesis tested using multiple regression. The contribution of the influence of attitude (ATT), subjective norms (SN), perceived behavioral control (PBC), moral obligation (MO), and past behavior (PB) to the intention (INT) to cheat (academic integrity) are tested to determine the effect contribution (R Square) to each variable. The test results of these variables presented as in Table 4.

The contribution of the independent variables to the dependent variable are respectively, student's attitude towards cheating intentions is 0.055 or $5.5 \%$, subjective norms to cheating intentions is 0.169 or $16.9 \%$, perceived behavioral control to cheating intentions is 0.076 or $7.6 \%$, moral obligation to cheating intentions is 0.083 or $8.3 \%$, and finally, the contribution of the influence given by past behavioral to cheating intentions is 0.044 or $4.4 \%$.

Based on the value of adjusted R square test, surprisingly, the highest influence intention to cheat in accounting students was subjective norms (SN), this variable had an effect of $16.9 \%$ on the intention of accounting students in cheating. By its definition, subjective norms are social factors that influence the attitudes or behavior of an individual to do or not do an action. Social factors can also be related to how the influence of family, close people around and the community environment on violations of academic integrity. Therefore subjective norms can influence the intensity of cheating. This result is also following research conducted by Mccabe, which states that the level of dishonesty of Lebanese students is higher than that of students in the USA, this is due to social factors or norms in Lebanese society, students raised to collaborate to complete challenging work (Mccabe \& Butterfield, 2006). In line with the issue, Hsiao (2015) pointed out that subjective norms were significantly related to cheating intention, peers attitude against cheating are are one of the most encouragement in to do so. Also, Hermawan \& Kokhunarina (2018) described that the environment was one of the most influential factors used to determine accounting ethical behavior students environment and family have an effect on their behavior.

Furthermore, the researchers had interview with ten respondents that had high score in answered the questions related to subjective norms questions in the questionnaire and by considering the respondent's GPA who achieve GPA above 3.5. The objective in determining respondents is that this research could ilustrate whether subjective norms can influace graduates behavior when cheating in assignments aand effect in students GPA. Most of the respondents said that their family or important people in their life or the society did not ask for the study process they only concerned fot the final grade or GPA. 
Dewanti, Purnama, Siregar \& Sukirno

Cheating Intention of Students Based on Theory of Planned Behaviour

Table 4. Regression Test Result

\begin{tabular}{lrrrr}
\hline \multicolumn{1}{c}{$\begin{array}{c}\text { Indepedent } \\
\text { Variables }\end{array}$} & R Square & $\begin{array}{c}\text { Adjusted R } \\
\text { Square }\end{array}$ & $\begin{array}{c}\text { Unstandardized } \\
\text { Coefficients (B) }\end{array}$ & t value \\
\hline Attitude (ATT) & 0.057 & 0.055 & -0.366 & -5.071 \\
Subjective Norms (SN) & 0.171 & 0.169 & 0.481 & 9.360 \\
Perceived Behavioral & 0.078 & 0.076 & -0.221 & -5.992 \\
Control (PBC) & & & & \\
Moral Obligation (MO) & 0.085 & 0.083 & 0.449 & 6.289 \\
Past Behavior (PB) & 0.046 & 0.044 & -0.369 & -4.535 \\
\hline
\end{tabular}

Source: Processed Data, 2019

The questions were, "My family advised me not to copy assignments or give my friend assignments to copy "(SN1)," When thinking about copying homework or give my homework to a friend to copy, I consider the values instilled by my family "(SN 3 ) and "If I copy a tasks or give my tasks to a friend to copy, the important people for my life (parents) will ..." (SN 2) fill in the answer with disagree and strongly disagree, which means that the subjective norms variable or social factors in the form of the influence of family and closest people do not reduce the intention of respondents to make the intention on assignment. The interview was conducted to confirm whether social factors such as family, close people and the environment were influence accounting students to cheat. Those social factors can lead to students pressure to get good grade, as stated in the research held by Bujaki et al., (2019) that pressures which one of the fraud triangle elements and get good grades is very srong deteminant of academic dishonesty.

The question raised by the researcher was about the GPA, parents' intention to give advice about honesty, and questioning the learning process during college or directly ask for the GPA. Interviewed with ten respondents, it was revealed that social factors in the form of norms or the influence of parents or family did not affect respondents to reduce their intentions in cheating assignments (PR), parents did not ask how the learning process, whether respondents did cheating or not and parents only focus on the result of the learning process in the form of a GPA

"Parents never ask about the learning process, just directly asking about the GPA, if the GPA goes down, then they are asked why the GPA has dropped. Parents also do not advise not to cheat, and parents are only focusing on the final results of the CPI "(Respondent 1).

"Parents never ask about the results of the GPA, usually I who tell, never also ask whether cheating or not, but usually I tell you that I have cheated assignments and friends have also cheated assignments and no response, I strongly agree with the view people who only judge the final results without seeing the process make the children also only think of the final results without thinking whether the process is correct or not "(respondent 2).

"Parents never ask about the learning process of high GPA cheating or not, when grades go down, new parents ask, my father advises to be honest because life is the most important thing, to be honest, but it is also not too often, in my opinion cheating the task is reasonable because we mutual help between friends "(respondent 3). "My parents never asked me if I did my assignment by cheating friends. They only asked whom I was working with, and my parents wanted my GPA cumlaude; usually, I did it by myself first ten i will look in my friends' homework to check it" (respondent 4). 


\section{Dewanti, Purnama, Siregar \& Sukirno \\ Cheating Intention of Students Based on Theory of Planned Behaviour}

"Parents have never asked in detail about the GPA only limited to understanding, I once cheated usually on a subject course, maybe parents do not know what indicators of success" (respondent 5).

"My GPA is 3.79, my parents never ask me whether i was doing my task or copy it from my friends, my parents and $\mathrm{i}$ have invited discussions about honesty, but usually about politics, parents never ask about the learning process, I usually cheat if my answers are different from my friends" (respondent 6).

"My GPA is 3.68, my parents never asked about the process, only the results, if the cheating cheat problem never asked if the value dropped, then I asked why the value dropped" (respondent 7).

"My GPA is 3.72, parents never ask about the process, only the results, rarely discuss honesty, I tell you if I cheat and who is cheating to me" (respondent 8)

"Since college, my parents have never asked the learning process only to ask about the results of the GPA, and I answered with numbers, I have given answers to my assignments to my friends because it is not good if not given to friends" (respondent 9).

"My GPA is 3.5, my parents have never asked about the process of achieving grades because I have been in college as an adult who understands what is right and what is terrible, I have discussed with parents about honesty because it is a value that has been planted and deeds sin, parents want to know my GPA is good without confirming in more detail "(respondent 10).

From the interview confirmation above, it can be concluded that parents did not ask about the learning process and only focused on the results of the respondents' GPA.

Moral obligation has the second biggest influence after subjective norms. Moral obligation refers to feelings of guilt or individual obligation to show or not show behavior to others. Cronan, in his research, stated that moral obligations reflect social values in a group where individual identity is located (Cronan et al., 2018a). Moral obligations have been predicted as one of the predictors of cheating intentions in some literature; moral obligations can also be a good predictor of ethical and unethical intentions. In his research, one of the hypotheses built by Cronan states that if an individual has a high moral obligation, then cheating intention behavior will low, the results of the research also support the hypothesis. Further, Duc Huynh (2020) confirmed that moral attitude could not predict the unethical behavior in cheating.

Contradict with the previous research, this research found moral obligation has the second-largest contribution after subjective norms, meaning that moral obligations can no longer reduce the intention of cheating behavior among students. Based on the interview, students openly acknowledged that they are doing cheating assignments to get high grades and high GPA, and this is also supported by the behavior of the group or classmates so that moral obligations do not affect ethical attitude or feelings of a student is behaving towards the intention to cheat assignments.

The third predictor is perceived behavioral control (PBC). It can be interpreted that PBC does not reduce intention in cheating. $\mathrm{PBC}$ is a variable that controls an individual's behavior by analyzing the level of difficulty of the behavior carried out (Beck \& Ajzen, 1991). Concerning of a scholars to commit academic cheating, when a student feels that academic cheating is easy and profitable to do both in doing the assignment, it will form the intention of the student to commit fraud in doing the assignment or doing the examination. This result was contradict with study held by Jalilian et al., (2016), 


\section{Dewanti, Purnama, Siregar \& Sukirno \\ Cheating Intention of Students Based on Theory of Planned Behaviour}

perceived behavior control is one of the strongest predictor in intention to cheat, the more understanding of individual on his ability to cheat the more the opporunity to commit cheating on exam.

The strong influence of moral obligation variables and perceived behavioral control conducted by Chudzicka-Czupała et al. (2016) on academic dishonesty in seven countries with 2,012 other respondents stating that attitude, perceived behavioral control and moral obligation are the main predictors of student cheating intentions. On the other hand this result was contradiction with the experiment that held by Wijayanti \& Putri (2016), The competence and opportunities graduates to act fraud in doing assignments will increase the desire of students to do the academic violation.

McCabe, Butterfield, \& Treviño (2012), Conclude based on their studies that cheating behavior develop long ago before college and that cheating in high school is widespread. Moreover, research conducted by Cronan et.al. (2018) on past behavior that individuals who have experience of high cheating intentions will affect high cheating behavior in the present. On the contrary this research result showed that past behavior give the lowest effect in intention to cheat in accounting students behavior. Past behavior can be in the form of student behavior before at university, mostly cheating behavior in high school. It can be conclude that that their experience has little influence on the intention to cheat.

\section{Conclusion}

It can be concluded that the variables contained in the TPB influence the intention of cheating assignments on students. The most influential variables are subjective norms, moral obligations and perceived behavioral control. The theory stated that if an individual has a high social value, especially those influenced by the family, then the intention to cheat assignments will low as well as moral obligations and perceived behavioral control. On the contrary, the research showed that subjective norms, moral obligations and perceived behavioral control were the most significant predictor in academic fraud especially in intention to cheat among accounting students and interviews with ten students confirmed it.

Furthermore, to follow up on the results of this research and in order to improve the quality of students' academic integrity so that cheating intentions can be reduced, this research proposes to officials in the university environment about the need for a review of the assessment of the learning process results, whether the GPA is still appropriate to be used as the only measuring tool in assessing the success of an individual in the learning process.

Also, the institution needs to immediately make a written policy to reduce the emergence of cheating behavior on students because of dishonest acts if done by almost all individuals in a group. Individuals will be carried away by groups to make such dishonest relations which in turn, this will can affect the individual character and will have an impact in the future.

This research is not without limitation, one of the limitations of this study is that it only examines the far-reaching influence of TPB factors on the intentions of cheating accounting students, so the results of this study cannot represent the detail causes of intention to cheat on accounting students. Also, another limitation is the possibility of students answering the questionnaires dishonestly, although it already explained earlier. 


\section{References}

Ajzen, I. A. (2002). Perceived Behavioral Control, Self-Efficacy, Locus of Control and the Theory of Planned Behavior. Journal of Applied Social Psychology, 32, 665-683. https://doi.org/10.1111/j.1559-1816.2002.tb00236.x

Ballantine, J. A., McCourt Larres, P., \& Mulgrew, M. (2014). Determinants of academic cheating behavior: The future for accountancy in Ireland. Accounting Forum, 38(1), 55-66. https://doi.org/10.1016/j.accfor.2013.08.002

Beck, L., \& Ajzen, I. (1991). Predicting dishonest actions using the theory of planned behavior. Journal of Research in Personality, 25(3), 285-301.

https://doi.org/10.1016/0092-6566(91)90021-H

Bujaki, M., Lento, C., \& Sayed, N. (2019). Utilizing professional accounting concepts to understand and respond to academic dishonesty in accounting programs. Journal of Accounting Education, 47, 28-47. https://doi.org/10.1016/j.jaccedu.2019.01.001

Chudzicka-Czupała, A., Grabowski, D., Mello, A. L., Kuntz, J., Zaharia, D. V., Hapon, N., ... Börü, D. (2016). Application of the Theory of Planned Behavior in Academic Cheating Research-Cross-Cultural Comparison. Ethics and Behavior, 26(8), 638659. https://doi.org/10.1080/10508422.2015.1112745

Creswell, J. W. (2018). Research Design : Qualitative, Quantitative, and Mixed Methods Approaches. SAGE Publications Inc. (Vol. Fourth Edi). https://doi.org/10.1017/СBO9781107415324.004

Cronan, T. P., Mullins, J. K., \& Douglas, D. E. (2018a). Further Understanding Factors that Explain Freshman Business Students' Academic Integrity Intention and Behavior: Plagiarism and Sharing Homework. Journal of Business Ethics, 147(1), 197-220. https://doi.org/10.1007/s10551-015-2988-3

Cronan, T. P., Mullins, J. K., \& Douglas, D. E. (2018b). Further Understanding Factors that Explain Freshman Business Students' Academic Integrity Intention and Behavior: Plagiarism and Sharing Homework. Journal of Business Ethics, 147(1), 197-220. https://doi.org/10.1007/s10551-015-2988-3

Duc Huynh, T. L. (2020). Replication: Cheating, loss aversion, and moral attitudes in Vietnam. Journal of Economic Psychology, 78(March). https://doi.org/10.1016/j.joep.2020.102277

Elijido-Ten, E. (2007). Combining qualitative and quantitative methods in environmental accounting research. 6th Australasian Conference on Social and Environmental Accounting Research, 2-4.

Hermawan, M. S., \& Kokhunarina. (2018). Factors Influencing Accounting Students' Perception Of Accounting Ethics: An Empirical Study In Indonesia. Jurnal Akuntansi Dan Bisnis, 18(2), 88-97.

Hsiao, C. H. (2015). Impact of ethical and affective variables on cheating: comparison of undergraduate students with and without jobs. Higher Education, 69(1), 55-77. https://doi.org/10.1007/s10734-014-9761-x

Ismail, S., \& Yussof, S. H. (2016). Cheating behavior among accounting students: some Malaysian evidence. Accounting Research Journal, 29(1), 20-33. https://doi.org/10.1108/ARJ-05-2014-0050

Jalilian, F., Moazami, P., Mirzaei-Alavijeh, M., Moazami, A. M., \& Jalili, C. (2016). Sensation seeking and the intention to cheating among college students: An application of the theory of planned behavior. Research Journal of Applied Sciences, 11(8), 645-649. 


\section{Dewanti, Purnama, Siregar \& Sukirno \\ Cheating Intention of Students Based on Theory of Planned Behaviour}

Jordan, A. E. (2001). College student cheating: The role of motivation, perceived norms, attitudes, and knowledge of institutional policy. Ethics and Behavior, 11(3), 233247. https://doi.org/10.1207/S15327019EB1103_3

Kabbanji, J. (2015). Superiority and Banality of the Qualitative Method: The Analytic Induction of Jack Katz. Méthod(e)s: African Review of Social Sciences Methodology, 1(1-2), 147-154. https://doi.org/10.1080/23754745.2015.1017283

Macgregor, J., \& Stuebs, M. (2012). To Cheat or Not to Cheat : Rationalizing Academic Impropriety. Accounting Education, 21(3), 265-287. https://doi.org/10.1080/09639284.2011.617174

Madden, T. J., Ellen, P. S., \& Ajzen, I. (1992). A Comparison of the Theory of Planned Behavior and the Theory of Reasoned Action. Personality and Social Psychology Bulletin, 18(1), 3-9. https://doi.org/10.1177/0146167292181001

Mccabe, D. L., \& Butterfield, K. D. (2006). Academic Dishonesty in Graduate Business Programs : Prevalence, Causes, and Proposed Action, 5(3), 294-305.

McCabe, D. L., Butterfield, K. D., \& Treviño, L. K. (2012). Cheating in college: Why students do it and what educators can do about it. Cheating in College: Why Students do it and what Educators Can do About it. https://doi.org/10.5465/amle.2014.0019

Pallant, J. (2010). SPSS Survival Manual. McGraw-Hill Education.

Schwartz, B. M., Tatum, H. E., \& Hageman, M. C. (2013). College students' perceptions of and responses to cheating at traditional, modified, and non-honor system institutions. Ethics and Behavior, 23(6), 463-476. https://doi.org/10.1080/10508422.2013.814538

Sekaran, U., \& Bougie, R. (2016). Research methods for business : a skill-building approach. John Wiley \& Sons, Seventh ed. https://doi.org/10.1017/СB09781107415324.004

Simkin, M. G., \& McLeod, A. (2010). Why do college students cheat? Journal of Business Ethics, 94(3), 441-453. https://doi.org/10.1007/s10551-009-0275-x

Tavani, H. T. (2013). Ethics \& Technology (4th Edition). Wiley.

Wijayanti, W. A., \& Putri, A. G. (2016). Model Theory of Planned Behavior (TPB) Untuk Memprediksi Niat Mahasiswa Melakukan Kecurangan Akademik. Fokus Manajerial, 14(2), 189-197.

Winrow, B. (2016). Do perceptions of the utility of ethics affect academic cheating? Journal of Accounting Education, 37, 1-12. https://doi.org/10.1016/j.jaccedu.2016.07.001 